\title{
The Oak Ridges Moraine as a Social Innovation: Strategic Vision as a Social-Ecological Interaction
}

\author{
Daniel D. P. McCarthy ${ }^{1}$, Graham S. Whitelaw ${ }^{2}$, Frances R. Westley ${ }^{3}$, Debbe D. Crandall ${ }^{4}$ and David Burnett $^{5}$
}

\begin{abstract}
The Oak Ridges Moraine (ORM) case is unique in that it represents a social innovation in Canadian, if not North American, ecosystem-based land-use planning. A social innovation is an initiative, product, process, or program that profoundly changes the basic routines, resources, and authority flows or beliefs of any social system. Successful social innovations have durability and broad impact. We interpret the narrative of the ORM conservation process to explore the utility of an emerging social innovation conceptual model, the 'vision as social interaction' framework using resilience thinking and the role of vision in social change within complex social-ecological systems. Qualitative data from two interrelated studies of the moraine were reinterpreted and include 38 in-depth, semistructured interviews conducted between 2004-2006, as well as extensive participant observation at over 50 moraine conservation meetings, workshops, and events. The results of our study indicate that emerging model of social innovation can be linked with other models of 'radical change' such as those that employ concepts like 'policy windows' to describe opportunities for continued innovation once an initiative has reached the routinized phase. Just as with the panarchy cycle, when a social-ecological system reaches the conservation phase, the system has a propensity to collapse and reorganize. Rather than seeing this as the end of an initiative or program, such as is the case with the ORM, stakeholders can see it as an opportunity for reorganization with newly released resources and new opportunities.
\end{abstract}

Key Words: Oak Ridges Moraine; social-ecological systems; social innovation; strategic vision

\section{INTRODUCTION}

By the mid- to late-1980s, development in the Greater Toronto Area (GTA) in Ontario, Canada had expanded north and had begun to threaten the fragile hydrogeology, geomorphology, and ecology of a major glacial moraine landform that served as an important green space corridor, the Oak Ridges Moraine (ORM; Fig. 1). It took over a decade of advocacy to secure Ontario provincial moraine-specific legislation in 2001 protecting almost $92 \%$ of the moraine from new urban development. More impressive is that this important and conservation-based environmental policy was enacted during an era of far-reaching neo-conservative, political economic trends toward smaller government and a market-based ethos. Furthermore, many of the regional conservation movement's most ardent advocates became involved initially in ORM-related issues for local interests, only to later embrace the entire moraine as a unique and ecologically sensitive landscape. We explore this impressive, if not unlikely, conservation success as a social innovation that began as a vision to protect the moraine and then evolved to address its complex and linked ecological, social, economic, and political systems.

A social innovation is "an initiative, product, process or program that profoundly changes the basic routines, resource and authority flows or beliefs of any social system. Successful social innovations have durability and broad impact" (http://sig. uwaterloo.ca/about-the-waterloo-institute-for-social-innovationand-resilience-wisir). Social innovations are by nature multifaceted. They may begin as an idea for a different way of doing things, developed by a leader or a social entrepreneur. However by the time that idea has had a broad impact on the way in which we relate to each other or to the natural environment, it
Fig. 1. Map of the Oak Ridges Moraine.

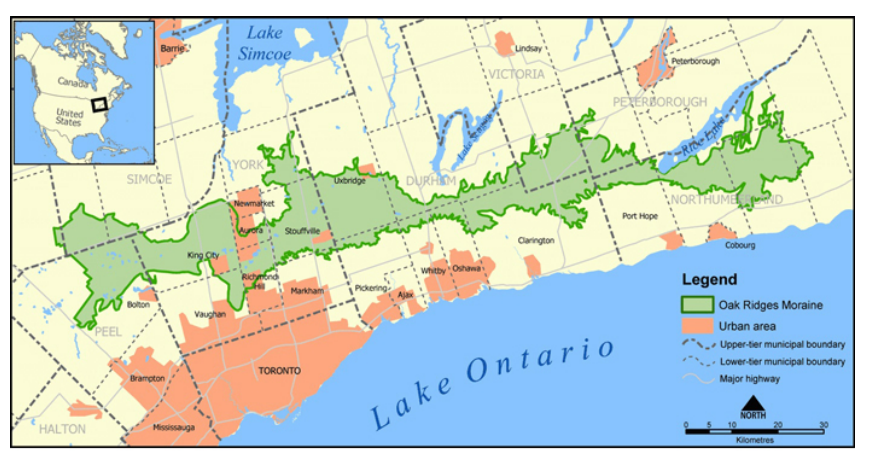

has evolved, transformed, or permuted into something more complex: a cluster of ideas, practices, resources, and relationships.

With our research, we make a novel contribution to the burgeoning literature on socio-technical transitions and social innovation (Loorbach and Rotmans 2006, Geels and Schot 2007, Smith 2007, Biggs et al. 2010, Geels 2011, Riddell et al. 2012, Smith and Raven 2012, Westley et al. 2013). The research on transition management describes a multiphase and multiscale model of socio-technical change (Loorbach and Rotmans 2006, Geels and Schot 2007, Geels 2011). Transition management research articulates the cross-scalar dynamics of such change

\footnotetext{
${ }^{1}$ Waterloo Institute for Social Innovation and Resilience and the Department of Environment and Resource Studies, University of Waterloo, ${ }^{2}$ School of Environmental Studies, Queens University, ${ }^{3} \mathrm{JW}$ McConnell Chair in Social Innovation, Waterloo Institute for Social Innovation and Resilience, ${ }^{4}$ Debbe Day Crandall Save the Oak Ridges Moraine Coalition, ${ }^{5}$ Manager, Regional and Provincial Policy, Toronto and Region Conservation
} 
through the protection of niche innovations, to changing sociotechnical regimes, to broader landscape change (Smith and Raven 2012). Recent work on social innovation within social-ecological systems links research on resilience (Gunderson and Holling 2002, Walker and Salt 2006) to strong social theory (Giddens 1984). Using the heuristic of the panarchy cycle, the concept of social innovation describes the dynamics of rapid social change as the dynamic tension between the behaviour of individual agents and broader social structures or systems (Biggs et al. 2010, Westley et al. 2013). We offer a model or heuristic process of social change that complements these conceptual contributions and further articulates various stages of an innovation, i.e., catalytic, articulated, legitimized, enacted, embedded, and routinized (Westley 1992). It does so by describing the evolution of an agent's vision of change in relation to the degree of organization/ institutionalization of the system or problem domain. It also builds on the work of Biggs et al. (2010) that links social innovation dynamics directly to the panarchy cycle by specifying phases of 'front-loop' innovation.

We interpreted the narrative of the ORM conservation process to explore in more detail how the initial idea transformed through time and networks into an innovative approach to ecosystem governance that has implications beyond the ORM itself (Whitelaw and Eagles 2007). In doing so, we sought to deepen the understanding of successful social innovation by tracking the transformations and permutations of ideas and resources through time. Drawing on a model of innovative 'vision as social interaction' (Westley 1992), we analyzed the ORM case as stages in an evolving vision, each stage in turn emblematic of shifts in rules, relationships, and resources at the system or problem domain level.

The ORM case is unique in that it represents an innovation in Canadian, if not North American, ecosystem-based, land-use planning (Whitelaw and Eagles 2007), and it also represents a compelling case of social learning and social change (Whitelaw 2005, McCarthy 2006, McCarthy et al. 2011). The ORM is located to the north of the City of Toronto and extends from the Niagara Escarpment in the west to the Trent River system in the east. The ORM is approximately 195,000 hectares in size, $160 \mathrm{~km}$ in length and between 3 and $24 \mathrm{~km}$ wide. It rises some 229 meters above Lake Ontario (Government of Ontario 2002). This case study focuses on the ORM land-use-planning process from 1988 to 2012. The ORM case involved a civil society advocacy initiative and planning movement that led to the area specific legislation, the ORM Conservation Act (ORMCA) in 2001 (Government of Ontario 2001) and development of the associated ORM Conservation Plan (ORMCP) in 2002 (Government of Ontario 2002).

Qualitative data from two interrelated studies of the moraine were reinterpreted and include 38 in-depth, semistructured interviews conducted between 2004-2006, as well as extensive participant observation at over 50 moraine conservation meetings, workshops, and events. The data were used to explore the ORM conservation movement as a social innovation and to contribute to the further development of the 'vision as social interaction' conceptual model. These qualitative data were supplemented by follow-up interviews with a variety of ORM stakeholders to verify our interpretation of the moraine conservation narrative in the context of the proposed conceptual model or heuristic.

\section{CONCEPTUAL BACKGROUND: SOCIAL INNOVATION IN COMPLEX SOCIAL-ECOLOGICAL SYSTEMS}

Our research builds on work that has applied complex systems thinking to resilience and to fostering adaptive capacity, social learning, and especially social innovation within complex socialecological systems (Gunderson et al. 1995, Berkes and Folke 1998, Kay et al. 1999, Gunderson and Holling 2002, Berkes et al. 2003, Waltner-Toews et al. 2004, Armitage 2005, Walker and Salt 2006, Westley et al. 2006, Biggs et al. 2010, Westley and Antadze 2010, McCarthy et al. 2011). Social innovation refers to new concepts, strategies, initiatives, products, services, processes, or organizations that meet pressing social needs and profoundly change the basic routines, resource and authority flows, or values and beliefs within the social system in which they arise (Westley et al. 2006, Mulgan et al. 2007, Biggs et al. 2010). Any process of social innovation consists of two key dynamics: (1) 'bricolage,' or recombining existing and new ideas to form something novel (Levi-Strauss 1962, Arthur 2009, Biggs et al. 2010); and (2) scaling up these ideas, i.e., the insertion of novelty into the dominant approaches to a particular issue domain involving translation, mediation, and opportunistic leveraging of resources and disturbances (Westley et al. 2006, 2011, 2013, Biggs et al. 2010, Gelchich et al. 2010).

Social innovation is a relatively recent arena for conceptual development, but the challenge of understanding how complex social systems change and transform is as old as the social sciences themselves. Macro social theorists starting in the 1850s with the work of Karl Marx, Max Weber, and Emile Durkheim struggled to understand how societies transform and under what conditions. Recent work describing the cross-scalar dynamics underlying a variety of social innovation processes invoke the work of Anthony Giddens (1976, 1979) and his theory of structuration to describe the dialectic tension between agents and different types of social structures (Westley and Antadze 2010, Moore and Westley 2011). This work describes how individual agents create different types of social structures through repeated behavior. In turn, agents become constrained by, and are given opportunities within, these structures. These structures constrain and enable the flows of resources, i.e., structures of domination; values and meanings, i.e., structures of signification; and rules of behavior, i.e., structures of legitimation; necessary for social interaction. The structures are experienced as objective, acting upon us, and yet we create and recreate them every day. Changing such structures begins by changing the microdynamics of conversation and behavior. Such experimentation, like much of social innovation, remains temporary, improvisational, and does not necessarily challenge the broader institutional structures (Giddens 1976, 1979).

The role of individual agency in social change and transformation has been studied from the works of Parsons (1951), Geertz (1957), and Weber (2009) and through the role of transformational leadership (Tushman and Rominelli 1985, Quist and Vergragt 2004, Woodhill 2010), and more recently through social or institutional entrepreneurship (Battilana et al. 2009). In complex, linked social-ecological systems that are the context of most of 
our seemingly intractable contemporary challenges, such transformation is rarely achieved through deliberate intervention on the part of actors; nor can they be explained solely by macroscale dynamics. Rather it is the interplay and relation between action and context through time that offers the best lens for understanding transformation. This points to the importance of ethnographic and longitudinal research to spur further conceptual development. Nuanced and textured accounts of the microdynamics of transformation and the role of agency in these transformations remain rare (for exceptions see Loorbach and Rotmans 2006, Geels and Schot 2007, Smith 2007, Geels 2011, Riddell et al. 2012, Westley et al. 2013).

One forum for understanding successful transformation may be found in a closely related field: that of visionary, charismatic, or transformational leadership. Leadership, particularly visionary leadership, can contribute to the creation of novel meanings and values. Although the novel meanings and ideas are often attributed to the mind of the leader, they are in fact socially negotiated and change over time (Westley 1992). Unlike the studies of charisma that have attributed its transformative capacity to attributes of the leader (see Conger and Kanungo 1998), others have seen charisma as a relational attribute, an interaction between leaders and followers (Selznick 1957, Weber 1978, Westley and Mintzberg 1989). This latter approach has greater affinity to complexity theory, with its notions of the need for fundamentally relational approaches as key to understanding complex system dynamics (Westley et al. 2006, Wheatley 2006, Whittingdon 2007, Senge 2010). But the need still remains to understand how those leader-follower relations evolve, transform, and permute over time. The more sophisticated analyses of charismatic or visionary leadership suggest that although it can be a game changer, the dynamics are subtle and social.

In one of the earliest studies of charisma as a form of authority, Weber (1978) identified a temporal dynamic that he labeled 'routinization of charisma' in successful innovative initiatives suggesting that for durability and scale ideas and relationships initially embodied in the leader-follower relationship must become part of the organization itself, indeed becoming institutionalized as Selznick (1957) pointed out.

Westley (1992) presents a more elaborated model of how the shifting relationships between leader and follower can be traced in the evolving innovation itself. In a case drawn from the introduction of palliative care into a teaching hospital, a radical innovation in a context in which even a good death was not viewed in any sense an institutional goal, Westley (1992) identified six stages, i.e., catalytic, legitimized, articulated, enacted, embedded, and routinized, through which the innovation embodied in the initial vision of the charismatic leader evolved. This approach helps to shed light on the relational dynamics that shape emerging innovations, from idea/vision created by a founder/leader to an institutionalized initiative. It also draws attention to the fact that even if an innovative idea can be traced to a single individual or organization, it soon becomes a social construction, involving a much broader actor set.

Innovation, therefore, which begins as an idea or vision can be analyzed as a social process, a particularly valuable representative of a powerful but evolving example of Gidden's (1976, 1979) 'structure of signification,' i.e, values and meanings. Such visions provide meaning and coherence, but evolve through various stages as actors or agents interact with social structures or the broader system (Westley 1992). They are altered and evolve based on interactions with others within and outside the immediate context in which they originated. The evolving idea is also shaped by the constraints and opportunities within social structures or the broader system. The six phases of the evolution of the strategic vision for the palliative care service, as presented by Westley (1992) included:

- Catalytic vision: urgent stimulus for the creation of the initiative, less a blueprint, than an awareness of an unmet need; highly idealized/simplified; and a search for understanding;

- Legitimized vision: highly political process of getting key resources mobilized; and the image of the initiative negotiated;

- Articulated vision: need to further 'frame' the initiative but lack of precise vision can actually help at this stage with negotiation; articulating the vision to different stakeholders to ensure buy-in; and flexible vision without being disingenuous;

- Enacted vision: vision articulated into specific undertakings/ projects; team approach essential; research aspect stressed;

- Embedded vision: no initiative has clearly defined boundaries, rather it is bound by formal and informal interactions which sustain, support, and also limit its existence; ongoing resources secured/stabilized; and networks initiated;

- Routinized vision: sense of distinction fades/energy diminishes; focus difficult to maintain; uncertainty about the future; and budget cuts shrink services.

We utilized these stages as a surrogate for the role of individual agents in a social innovation process. Our novel contribution is that we juxtaposed these stages with, or set in relation to, a description of the state of the social structures (Giddens 1979) or the broader system dynamics (Gunderson and Holling 2002, Walker and Salt 2006). We have constructed a conceptual model or heuristic of social innovation (Fig. 2) that describes the innovation process as happening in dynamic tension between the evolution of an agent's vision and the evolution of relevant social structures or opportunities/constraints afforded by the broader system.

This heuristic of social innovation arising in dynamic tension between an individual agent's vision and the opportunities and/ or constraints provided by broader, relevant social structures/ systems was applied to the ORM conservation movement as a case study of social innovation in the field of environmental landuse planning. This application helped to empirically ground and test the model's efficacy. 
Fig. 2. The vision as social construction heuristic.

\section{Innovations that Cross Scales}

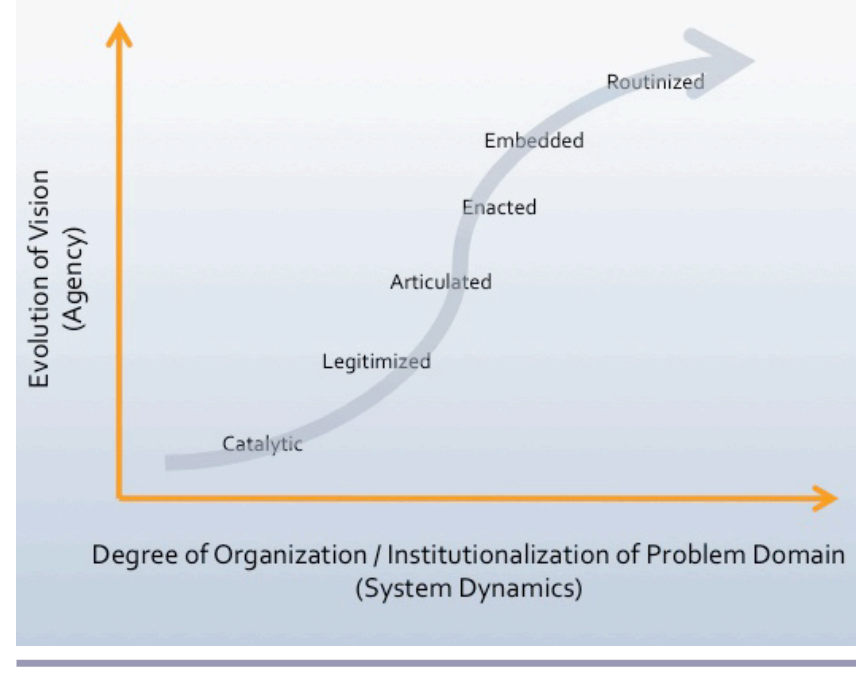

We present this conceptual model as a heuristic that can help practitioners and researchers to better understand the innovation process and diagnose potential barriers to, and opportunities within, an innovation process by articulating general phases or stages within such processes. These stages are presented as loose categories of activities. We encourage the use and adaptation of this heuristic in other historic and ongoing cases of innovation processes to further refine and possibly combine the presented stages.

\section{METHODS}

We reinterpreted empirical data originally collected and analyzed in the context of two, related research projects that focused on the development of the Oak Ridges Moraine conservation movement and its outcomes from actor systems and social learning perspectives (Whitelaw 2005, McCarthy 2006). The narrative of the ORM conservation movement was then reinterpreted through a social innovation perspective and additional empirical data was collected to support and verify the analysis.

The original studies and the current analysis utilized a case study approach (Yin 2003) through participatory action research (Whyte 1991). As a research strategy, case studies are used in many situations to "improve our knowledge of individual, group, organizational, social, political and related phenomena" (Yin 2003:1). The need for case studies arises out of the desire to understand complex social phenomena; a case study allows investigators to retain the holistic and meaningful characteristics of real-life events, such as organizational and managerial processes (Yin 2003). The Oak Ridges Moraine case study was used to explore the relational dynamics between actors/ charismatic visionaries and the relevant social structures/system.
The case deals with events over a period of more than two decades, which allowed for an in-depth, longitudinal understanding of the dynamics of an innovation process in a complex, linked socialecological system. This type of in-depth, longitudinal case study of complex, linked social-ecological systems has been used to inform the development of the field of resilience thinking (Gunderson et al. 1995). Participatory action research requires a partnership between academic researchers and reflective practitioners in the relevant case (Whyte 1991). Our research was conceived, developed, and implemented collaboratively with representatives from various organizations and groups across the Oak Ridges Moraine landscape.

The two original case study methods included key-informant interviews, policy document analysis, and participant observation. These original data sources provide the empirical basis for this current work (McCracken 1988, Creswell 1994, Berg 1998, Neuman 2000, Flyvbjerg 2001, Lewis 2003, Whitelaw 2005, McCarthy 2006). The empirical data from these two original studies were reinterpreted through a social innovation lens using a themed analysis (Strauss 1987, Maxwell 1996).

Interviewing allows the researcher to gain an in-depth, detailed account of the social-ecological and policy context of the respondents and their individual perspectives (Fontana and Frey 2003, Lewis 2003). In total, 38 interviews were conducted for the Oak Ridges Moraine case study between 2004-2006. Complex processes or structures are best captured using in-depth interviews because they provide a depth of focus and the opportunity for detailed explanation and clarification. Specifically, interviewing allows the researcher to gain an understanding of the complex process of social and policy change (Lewis 2003).

Two sets of standard questions were asked of each interviewee in a systematic and consistent order. However, the interviewees were allowed the freedom to digress. That is, the interviewers were permitted, in fact expected, to probe far beyond the answers to their prepared and standardized questions (Berg 1998). Interviewees were chosen based on their experience with the Oak Ridges Moraine planning and policy process from 1988-2005 as identified through an initial screening with long-standing members of the ORM conservation movement. Snowball sampling was also used in the context of the interviews to identify other potential interviewees. Snowball sampling generally refers to the identification of potential interviewees based on the recommendation of previous informants (Berg 1998, Ritchie et al. 2003). It is particularly useful as a sampling technique for groups that are small and connected only by a particular interest, such as professional expertise (Ritchie et al. 2003).

In the context of the interviews, each respondent was also asked to identify the key documents for understanding the issues and events associated with the Oak Ridges Moraine land-use planning process between 1988 and 2005. In the follow-up email, a request was made to respondents for documents that they had offered to acquire on our behalf. Once all available documents were acquired, they were systematically reviewed as a means of triangulation. For each policy document, its purpose, content, and significance for the research were described. The policy document analysis was used to verify details regarding key events, key individuals, groups, organizations, agencies, the role of knowledge and learning, and resulting shifts in policy identified 
in the context of the interviewees' narrative descriptions of the ORM policy development process.

Aside from interviews, qualitative data was gathered for the case study by attending and participating in meetings and workshops. Participant observation refers to "research that involves social interaction between researcher and informants in the milieu of the latter, during which data are systematically and unobtrusively collected" (Taylor et al. 1984:15). Detailed notes were kept on the content and context, e.g., group dynamics and nonverbal responses, of meetings.

Additional interviews were carried out with key Oak Ridges Moraine stakeholders to verify our reinterpretation and extend our analysis through to 2011 (McCraken 1988, Berg 1998). After these follow-up interviews, a summary document detailing our findings was circulated to these stakeholders providing the opportunity for additional verification and clarification of our reinterpretation.

\section{THE OAK RIDGES MORAINE CONSERVATION PROCESS AS A SOCIAL INNOVATION}

There appears to be a strong fit between some of the key events in the ORM narrative and the conceptual model described above based on Westley's (1992) strategic vision activity clusters. We explored the utility of this conceptual model using the ORM narrative by linking the various activity clusters to events in the ORM conservation process. Although the categorization of activities or activity clusters to each of the stages of the heuristic is somewhat arbitrary, the research team engaged various stakeholders, embodying multiple perspectives, in the ORM conservation process to aid in, and verify, the categorization. The heuristic was found to be unanimously useful by the stakeholders to describe the ORM conservation process as an innovation. The authors believe that the heuristic can be usefully applied to other cases, and we encourage the use and adaptation of the model to other empirical cases.

\section{Catalytic vision}

The early, broad vision of the need for moraine conservation relates strongly to the catalytic vision activity cluster (Fig. 3). Advocacy was a key facet to the development of the catalytic vision. In interviews with advocates, researchers, and civil servants involved in the early days of moraine conservation, it was clear that there was an urgent, unmet need to conserve the ORM. It was an idealized and simple call for conservation and information gathering.

In the late 1980 s, early in the moraine conservation process, one of the key local groups, the Concerned Citizens of King Township $(\mathrm{CCKT})$, started two issue-based subcommittees on rural landuse policy and the Oak Ridges Moraine. Two environmental movement interviewees indicated that the chair of the Save the Oak Ridges Moraine (STORM) subcommittee of CCKT called a meeting in the fall of 1989 on the emerging issue of moraine conservation, tapping into the existing environmental stewardship network and had nearly two dozen people from all across the moraine attend. This meeting was credited with the emergence of the moraine conservation movement, and the birth of the main, moraine advocacy organization, the Save the Oak Ridges Moraine (STORM) Coalition. Three environmental movement interviewees indicated that they had been living on the moraine but did not recognize its significance. One environmental movement interviewee stated that she had been "living on the moraine since 1969 and I didn't even know what it was and I didn't know what an aquifer was." The committee started with small steps, an environmental movement interviewee indicated that, "we had buttons made up and did a brochure that was simplicity itself. In fact, it was criticized because it was too simple minded, it had to do with forests and water. I was wearing the button everywhere, a person on a subway knew what a moraine was, but didn't know what the Oak Ridges Moraine was, so I'd tell them and they'd say, 'what are you going to do with it when you save it."' Another of the environmental movement interviewees, in describing the early phase of the moraine movement noted: "there was an informal network that came alive and the message of the ORM meant something to all of those people." Through this early catalytic process, one image that was mentioned by six interviewees was a map commissioned by John Fisher, a then activist graduate student, for a publication on the moraine. It was a simple map of the moraine linked to the watersheds of the region. "It was an 'ah-ha' moment for me, seeing the moraine at the headwaters of all those major river systems flowing down through Toronto; it was so much more than "not in our back yard."”

Fig. 3. The vision as social construction heuristic applied to the Oak Ridges Moraine conservation process.

\section{Oak Ridges Moraine}

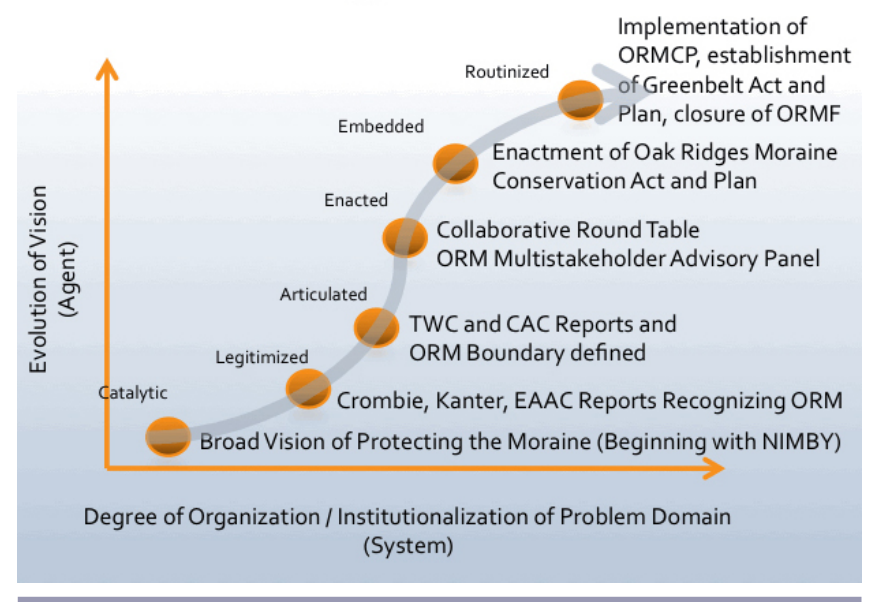

Other interviewees focused on growth beyond NIMBYism to a broader understanding of the ORM as part of the public good. The following are quotes from environmental movement interviewees:

People get involved at the lower step of the staircase, and one of the first steps that people take is that they realize that's going to have these negative effects [on me]. And inevitably, they go up a few stairs, and eventually these people can move up to be actually quite broad thinking, and not just self-interested, but the first way you usually get involved [is] through your own interests. That's what makes you want to make the time, and take the trouble. It's part of an educational staircase, so it really bothers me that people dismiss the NIMBY syndrome. 
A conservation authority interviewee stated:

Maybe when the moraine was just a local issue, maybe it was NIMBY driven, but the NGO groups did a marvelous job of broadening the appeal and the importance of the moraine so that there was just a huge groundswell of public opinion, which takes it out of the realm of NIMB Yism and really then says this is a highly valued public good that needs to be protected for all the public and not just the few folks who live there.

A provincial planner indicated that:

The broader public interest really came into effect here, when people were just saying: 'we're sick and tired of seeing subdivision after subdivision after subdivision grow, not just in our community but in the whole Toronto area. This has got to stop, this makes no sense.' I don't call that NIMBY, I call [that)] people being afraid of what the larger community's going to look like in 30 years. So I think there is some altruism in some of it.

The search for understanding the threats to the local environment by environmentalists led to a catalytic vision that eventually encompassed the entire moraine as part of a larger bioregion. For this broad, catalytic vision to evolve into conservation action it had to be legitimized.

\section{Legitimized vision}

The early, broad, and idealistic vision of moraine conservation was legitimized through a more political process of mobilizing resources (Fig. 3). Collaboration was a key element of the evolution of the vision to save the moraine. A conference entitled, "Greenways and Greenspace on the Oak Ridges Moraine" held in 1990 at Trent University, as well as three key government reports (Lucyk et al. 1989, Kanter 1990, Royal Commission on the Future of the Toronto Waterfront 1992) recognized the ORM as a significant landscape and began to legitimize the early catalytic vision of moraine conservation. An academic/environmental movement interviewee noted: "this [the Greenways conference] really started to legitimize the movement behind the ORM. [It] had Trent University, had Crombie (former Mayor of the City of Toronto and Chair of the Royal Commission on the Future of the Toronto Waterfront), had top-class speakers [so] people started to jump on this bandwagon."

During the early 1990s, the provincial government was actively working on natural heritage system planning in southern Ontario, and this work benefitted the ORM conservation initiative. One of these initiatives was led by Member of Provincial Parliament (MPP) Ron Kanter. An environmental movement interviewee elaborated on this:

I simply requested time to make a presentation to him [Kanter], which we did, down at Queen's Park we were there from supposedly three till four, and he had supposedly another meeting at four. At five o'clock he was still looking at our slides and talking to us about it. We were sitting on the floor in his office, you know, with the slide projector going.

Kanter received and endorsed the information from STORM representatives including the Fisher map that linked the ORM to its major watersheds and included a map of the ORM and a recommendation to protect the ORM in his final report (Kanter 1990). The second key report that legitimized the ORM conservation vision was prepared by the Environmental Assessment Advisory Committee (EAAC). An environmental movement interviewee recounted how the original EEAC hearing, which led to the report, was convened.

It was an accident. I [SAGA volunteer] sat down one day with the Toronto phone book and started phoning everybody [government] that had environmental in the name [laughs]. I was asking: 'do you know of any studies that talk about the impact of development on watersheds? 'And most of the people really didn't know what I was asking. But I happened to come to the Environmental Assessment Advisory Committee, and the woman said: 'well, I don't know, I'd better let you speak to somebody here.' So she put me on to a lawyer, who was in the office who did a lot of work for them, and he said: 'I don't know of any specific studies, but,' he said, 'this is what you ought to do. Write a letter to the Minister of the Environment and ask for an Environmental Assessment Advisory Committee [hearing],' he said. 'We have been, up until this point, basically assessing applications on the basis of the four corners of the lot. Cumulative impact, the broader thing, was never...it wasn't thought of.' He says: 'we're beginning to feel that it needs to be.' So we decided that that's what we would push for. The broader view. And therefore, we asked for the whole Ganaraska Watershed [to be the subject of a hearing]. Well, we had no idea, we just went through this process because he had suggested it, and it was happenstance.

With the environmental movement having successfully collaborated with the EAAC, the breadth of cumulative impacts associated with numerous developments across the moraine became recognized as an important issue to be dealt with through planning. Similar to the Kanter report, the EAAC report (Lucyk et al. 1989) recognized the entire ORM and called on the government to protect it. The third government study was the Royal Commission on the Future of the Toronto Waterfront led by David Crombie. A government interviewee identified the significance of both Crombie and Kanter's reports.

Well, it really goes back to Ron Kanter and David Crombie, in my mind... Anyway, he's [Crombie] the one who sort of painted the landscape scale, the interregional scale that we need to look at things from that perspective. And Kanter certainly took it to the next level, in terms of the Moraine specifically, or, I guess Crombie even talked about the Moraine.

The STORM Coalition worked hard at placing the ORM into a provincial context as indicated by the following two quotes from environmental movement interviewees:

Since we'd been so successful with our slideshow [with MPP Ron Kanter], we took this show down to the waterfront, because I'd made the point somewhere along the line, to David Crombie that there was no point in them cleaning up the mouth of the Don [River] unless he did something about the source of the Don [River]. So we had... STORM fairly well had a good chunk of the 
afternoon to present to him and I remember Kathy Guselle did a wonderful presentation, and I did our little bit again, almost identical to what we'd given Kanter. Yes, [we did have influence] the fact that we were highlighted in those [reports of the Commission: Watersheds and Regeneration ], in my books they're highlighted anyway.

That presentation was good practice for David Crombie's waterfront stuff. Both of Crombie's books have many quotes from [members of the STORM Coalition]. The point was that you can clean up the mouth of the Don [River] as much as you like, but if you don't protect the headwaters then it won't add up to much. Met with David Crombie several times as a kind of mentor. Some of his advice was that they wouldn't get everything that they wanted.

The above quotes indicate the effort taken by the environmental community to expand the discourse of the ORM from addressing individual developments separately to thinking about overall conservation and governance of the entire landscape. This vision helped legitimize the Oak Ridges Moraine and its importance to natural heritage planning and to water quality and quantity protection in southern Ontario.

\section{Articulated vision}

Collaboration continued to be a key component of the evolution of the vision of moraine-wide conservation. The vision was more clearly articulated through a key report jointly produced by the ORM Technical Working Committee (TWC) and the Citizens' Advisory Committee (CAC; Fig. 3; ORM Technical Working Committee 1994). The TWC and CAC were created to oversee a three-year provincial planning study for the GTA portion of the ORM in 1991. The overall purpose of the study was to frame the ORM conservation initiative and to contribute to a deeper understanding of the moraine's ecology to ensure the buy-in of a variety of stakeholders for bioregional conservation planning. The TWC comprised representatives of three provincial ministries, i.e., Natural Resources, Environment, Municipal Affairs, the three Regional Municipalities of Peel, York, and Durham, conservation authorities, i.e., Ganaraska and Toronto and Region, and interest groups such as the Aggregate Producers Association of Ontario, Urban Development Institute, Federation of Ontario Naturalists, Conservation Council of Ontario, and the STORM Coalition. A Citizens' Advisory Committee was also struck to carry out public consultation on the study and strategy formulation. Fifteen background studies and mapping products were completed between 1991 and 1994 and a recommended strategy based on an ecosystem approach was formulated. An ecological framework to manage and protect the ORM was proposed, which consisted of the integration of the Natural Heritage System, the Water Resource System, and the Landform Conservation System. The strategy for the longterm protection and management of the ORM within the GTA was submitted to the Minister of Natural Resources (MNR) in November 1994. The provincial government changed shortly thereafter and no adoption of or action on the strategy document by the province occurred (Burnett 2002).

The TWC and CAC processes were both a success and a failure in the overall planning process. A government interviewee stated:

The Technical Working Committee was in the embryonic stages of working through true partnership models with the stakeholders; there was a lot of information sharing, there was a lot of testing, there was a lot of understanding of everybody's position on things. The good thing about the early stages of the Technical Working Committee, although it didn't result in the actual development of the Plan, what it did, though was established a baseline of knowledge and information that was invaluable when we started into the final phases. People were up to speed on the issues, they were up to speed on the lingo, they were aware of the capabilities and interests of others, so although it didn't result in something concrete, I think it was good for building a comfort level between a lot of the stakeholders. [The process] gave us such a great head start [to the final ORM planning process that was to occur in 2001].

An environmental movement interviewee indicated:
.... that the TWC was the springboard for the science to be generated, this made it easy for the ministry (MNR) staff to generate the maps upon which land use planning could take place [during the final stages of the ORM planning process].

The efforts of the TWC and CAC further articulated a landscapelevel vision for ORM conservation and clearly steered the discourse toward bioregional planning. The resulting background studies, legitimacy, and quality of the process ensured broad stakeholder buy-in for moraine-wide conservation.

\section{Enacted vision}

The vision of moraine conservation was enacted, that is, further articulated through the work of a collaborative round table, known as the ORM Advisory Panel (Fig. 3). The ORM Advisory Panel focused their work with the idea of making specific recommendations for a bioregional plan; exhibited a multistakeholder, team approach; and utilized scenario-based research to create a natural heritage system that all stakeholders could support. The success of the advisory panel was elaborated on by three of its participants, an environmental movement representative, a government support staff person, and a private sector representative. The environmental movement representative noted:

The ORM Advisory Panel process was a success because it reached consensus on an approach to protect the ORM, one the government implemented. The make-up of the panel included a wide range of interests. The panel, although originally to report through an interministerial committee, managed to change the reporting structure and report directly to Minister Hodgson.

The panel had access to the TWC information as well as new information generated since 1994. Provincial government respondents provided the following insights into its success:

With the advisory panel, I think there was urgency and a focus on everybody involved that there needed to be something done. So there was the focus and there was the will at the political level. The individual that led the advisory panel, Ron Vrancart, basically always said, 'that until the time is right, nothing will ever happen.' And I guess at that point in time, the time was right. But again, if there wasn't that relationship and that synergy 
created with the advisory panel, it still wouldn't have happened. I think you can't discount how successful that was.

A private sector respondent provided these insights into the success of the ORM Advisory Panel:

I didn't think there would come a day five years ago, that there would be a meeting of the minds at a very high level. Those types of groups, sorry, particularly NCC [Nature Conservancy of Canada] and the FON [Federation of Ontario Naturalists] and even Save the Oak Ridges Moraine, we can sit down, have a healthy debate, and agree on some very high-level principles.

The ORM Advisory Panel was established 12 years after the initial catalytic visioning by the environmental movement. By that point extensive research was available for use through a collaborative team effort that had wide, political support, and this is how the ORM conservation vision became enacted.

\section{Embedded vision}

The vision of moraine-wide conservation was embedded through the enactment of the Oak Ridges Moraine Conservation Act and the implementation of the associated ORM Conservation Plan, the creation of the Conservation Authorities Moraine Coalition (CAMC), and the establishment of an Oak Ridges Moraine Foundation through a $\$ 15$ million fund to support on-the-ground stewardship, land securement, and trail development projects (Fig. 3).

In December of 2000, the nine conservation authorities, i.e., the quasi-government, watershed-based conservation organizations, with watersheds on the ORM, formally joined together as the Conservation Authorities Moraine Coalition (CAMC). The goal of the CAMC was to advocate for the protection of ecological features, functions and form of the moraine, to conduct scientific watershed studies to support an appropriate policy framework to guide land uses on the moraine, and to achieve a 'green corridor' vision of protected lands across the ORM. The nine conservation authorities of the CAMC are: Nottawasaga Valley, Credit Valley, Toronto and Region, Lake Simcoe Region, Central Lake Ontario, Kawartha, Ganaraska Region, Otonabee, and Lower Trent (Burnett 2002). This new network of conservation practitioners has emerged as the 'back-stop' for the implementation of the ORM Conservation Plan.

On December 13, 2001, Bill 122, An Act to Conserve the Oak Ridges Moraine by providing for the Oak Ridges Moraine Conservation Plan, passed third reading in the Ontario Legislature and received Royal Assent on December 14, 2001. The act provided for the establishment of the ORM Conservation Plan by regulation and set out its objectives (Burnett 2002). The plan, approved and filed as a Minister's regulation on April 22, 2002, implements the objectives of the act to protect the ecological and hydrological integrity of the ORM (Burnett 2002). As previously mentioned, the plan provides various levels of protection and associated permitted uses in four land-use designations: natural core, natural linkage, countryside area, and settlement area. The plan is implemented through a conformity exercise with the relevant municipal government official plans and zoning by-laws.

In 2002, the Oak Ridges Moraine Foundation (ORMF) was started with an investment of $\$ 15$ million from the Province of
Ontario. Since opening its doors, the ORMF has efficiently granted \$14.1 million to 177 projects and leveraged an additional \$35.8 million (http://www.moraineforlife.org/). The establishment of the ORMF secured and stabilized financial support for conservation, stewardship, and research complementing the regulatory protection afforded by the ORM Conservation Act and Plan.

The development of the CAMC, the ORM Conservation Act and Plan, and the establishment of the ORMF have created a suite of formal, i.e., legislative, regulatory, and funding, and informal, i.e., conservation, research, and stewardship networks, social structures. These structures define the ORM conservation and stewardship movement for the next decade.

\section{Routinized vision}

The ORM conservation vision has been routinized through a decade of ORMCP implementation, the establishment of the Greenbelt Act and Plan, and the potential closure of the ORMF (Fig. 3). The year 2012 marked a decade since the enactment of the ORMCA and ORMCP and the establishment of the ORMF. However, despite the innovative nature of the ORM Conservation Act and Plan being one of the first land-use policies to embody landscape ecology and conservation biology principles (Whitelaw and Eagles 2007), the distinction and energy around moraine conservation have indeed faded. Clear evidence of this is the establishment of Ontario's Greenbelt Act and Plan and the Friends of the Greenbelt Foundation (FGF).

Established in 2005, the Greenbelt spans 1.8 million acres across southern Ontario. The area stretches 325 kilometers from Rice Lake in Northumberland County to the Niagara River, is about 80 kilometers wide at its widest point, and encompasses both the Niagara Escarpment and Oak Ridges Moraine Plan areas. Created by legislation in February of 2005, the purpose of the Greenbelt is to protect key environmentally sensitive land and farmlands from urban development and sprawl. A former government interviewee indicated that the "liberal government tried to supplant ORMCP vision with a bigger, better, and grander Greenbelt vision: viewed by some as an attempt by the Liberal Government to "rebrand" the old Conservative Government ideas." Indeed, the development of the Greenbelt has contributed to the loss of distinction and energy around moraine conservation. The Greenbelt has also wrested key financial support away from the ORM conservation movement.

The Friends of the Greenbelt was established in June of 2005 with an initial \$25 million dollar grant from the province. And in 2012, the Government of Ontario had allocated a total of \$25 million of funding to the Friends of the Greenbelt Foundation. Despite a vigorous campaign by ORM supporters, the ORMF did not receive refinancing by the province and has reduced its staff capacity and thereby extended its resources so as to play a role in the 2015 plan review. This will have a devastating impact on the moraine conservation movement because the ORMF has not only provided leadership but also key financial support for the development of moraine-focused, nongovernment conservation and stewardship organizations. These organizations include, the STORM Coalition, the Oak Ridges Moraine Land Trust, the Oak Ridges Trail Association, and the Caring for the Moraine network, which has brought together 30 conservationminded organizations on the Oak Ridges Moraine to deliver critical landowner stewardship services. Without the dedicated 
financial support for moraine-specific and conservation and stewardship-first programs and projects, the future of these organizations is now in question. With the 2015 plan review looming, the ORM conservation movement faces some uncertain and challenging times.

\section{DISCUSSION}

We presented the 'vision as social construction' model as a heuristic to help describe front-loop innovations (Biggs et al. 2010). As such, it is not presented as fait accompli, but rather as a working model of front-loop innovation to be further tested, refined, and adapted in subsequent cases. We acknowledge that it may be difficult to clearly demarcate or differentiate various activities into the loose categories or stages within the heuristic, however we addressed this in our case through the use of multiple perspectives on the ORM conservation process. Oak Ridges Moraine stakeholders unanimously described the heuristic as useful in articulating the ORM process as a social innovation, and we argue that it can enrich the discourse and practice of social innovation.

There are two main conceptual contributions. The first is the recognition that in complex systems, an original, innovative vision, even if it can be traced to an individual leader, rapidly becomes owned by a larger network. This larger network and its additional capacity are essential for the transformation that follows. In the ORM case study context, a group of early actors managed to bring together a coalition of environmental movement organizations, partnered with government staff, who influenced on-going government studies that all, ultimately brought together a larger network that successfully transformed ORM environmental planning and governance.

Second, the vision as social construction model provides researchers and practitioners with a more nuanced conception of the social innovation or transformation process beyond that which currently exists in the relevant literature. That is, the model clearly articulates six potential stages of the interplay and relation between the action of individual agents and the relevant context or system. In the case of the ORM, an initial, catalytic vision to save the moraine was legitimized by influencing several government studies. The vision was then articulated and eventually enacted through two multistakeholder, collaborative government committees that defined the ORM as a planning entity. This resulted in an embedded vision of the Oak Ridges Moraine Conservation Act and Plan and has been routinized through over a decade of ORMCP implementation. This conceptual model and its application to the ORM case can give researchers and practitioners who study and foster social innovations in linked social-ecological systems an interpretive and diagnostic tool for understanding how innovations occur and for identifying potential barriers and opportunities.

Examination of this decades long, regional, environmental planning process through the lens of social innovation, provides practical guidance for fostering transformation in environmental governance. Specifically, the conceptual lens illustrates the roles of advocacy, collaboration, and implementation as part of an environmental planning and management social innovation, as well as the links among the three. In the case of the ORM, advocacy mainly occurred through the catalytic vision phase, however from a practical perspective, advocacy had to be maintained throughout all of the phases, in particular by civil society groups. Collaboration was most important at the articulated and enacted vision phases in which stakeholders came together and agreed on an approach for implementing an innovative environmental planning and management policy. Implementation activities occurred mainly at the embedded vision phase and have subsequently become routinized, and we see that the resilience of the ORM planning and governance systems may be eroding as a result of changing government priorities, i.e., Ontario's Greenbelt Act. To ensure the resilience of the ORM governance system, actors need to draw upon both advocacy and collaborative approaches so that the implementation remains relevant and continues to evolve.

\section{RECOMMENDATIONS FOR FUTURE RESEARCH}

The authors recommend further empirical grounding of this heuristic to verify its utility in both interpretive, i.e., historical or existing innovation, and diagnostic, i.e., emerging or potential innovation, contexts. The authors would recommend exploration of potential conceptual links to the panarchy cycle's front loop (Biggs et al. 2010). As well, the authors recommend the extension of the heuristic through potential connections to related backloop social innovation models (Biggs et al. 2010). This may provide a provocative and potentially robust model of the innovation process that would highlight insights for innovation processes that have reached the routinization phase of the model.

In the context of the ORM case, because the moraine conservation movement has reached the routinized phase of the model, moraine stakeholders should be looking for windows of opportunity or policy windows (Kingdon 1995) to revitalize the moraine movement. It is critical to have an existing solution (Kingdon 1995) or 'shadow' alternative (Olsson et al. 2006) to be able to effectively take advantage of such a window. In the case of the moraine, the emerging UNESCO Biosphere Reserve nomination, with its broad sustainability mandate may be a complement to the conservation-focused moraine movement to date.

Responses to this article can be read online at: http://www.ecologyandsociety.org/issues/responses. $\mathrm{php} / 6212$

\section{Acknowledgments:}

The authors acknowledge both the J. W. Mc Connell Foundation and the Social Sciences and Humanities Council of Canada for their generous support of this work. We also thank the participants working on the Oak Ridges Moraine for their time in this study as well as for their on going stewardship work. We also thank Erin Alexiuk for her help finalizing the manuscript.

\section{LITERATURE CITED}

Armitage, D. R. 2005. Community-based narwhal management in Nunavut, Canada: change, uncertainty, and adaptation. Society and Natural Resources 18(8):715-731. 
Arthur, W. B. 2009. The nature of technology: what it is and how it evolves. Free Press, New York, New York, USA.

Battilana, J., B. Leca, and E. Boxenbaum. 2009. How actors change institutions: towards a theory of institutional entrepreneurship. Academy of Management Annals 3(1):65-107. http://dx.doi.org/10.1080/19416520903053598

Berg, B. L. 1998. Qualitative research methods for the social sciences. Third edition. Allyn and Bacon New York, New York, USA.

Berkes, F., and C. Folke, editors. 1998. Linking social and ecological systems. Cambridge University Press, Cambridge, UK.

Berkes, F., J. Colding, and C. Folke. 2002. Navigating socialecological systems: building resilience for complexity and change. Cambridge University Press, Cambridge, UK. http://dx.doi. org/10.1017/CBO9780511541957

Biggs, R., F. R. Westley, and S. R. Carpenter. 2010. Navigating the back loop: fostering social innovation and transformation in ecosystem management. Ecology And Society 15(2): 9. [online] URL: http://www.ecologyandsociety.org/vol15/iss2/art9/

Burnett, D. 2002. Witness statement of David Burnett. Ontario Municipal Board Hearing, Case No. PL000037 and PL000180. Ontario Municipal Board, Toronto, Ontario, Canada.

Conger, J., and R. N. Kanungo. 1998. Charismatic leadership in organizations. Sage, Thousand Oaks, California, USA.

Creswell, J. W. 1994. Research design. Sage, Thousand Oaks, California, USA.

Flyvbjerg, B. 2001. Making social science matter: why social inquiry fails and how it can succeed again. Cambridge University Press, Cambridge, UK. http://dx.doi.org/10.1017/CBO9780511810503

Fontana, A., and J. H. Frey. 2003. The interview: from structured questions to negotiated text. Pages 61-106 in N. K. Denzin and Y. S. Lincoln, editors. Collecting and interpreting qualitative materials. Sage, Thousand Oaks, California, USA.

Geels, F. W. 2011. The multi-level perspective on sustainability transitions: responses to seven criticisms. Environmental Innovation and Societal Transitions 1(1):24-40. http://dx.doi. org/10.1016/j.eist.2011.02.002

Geels, F. W., and J. Schot. 2007. Typology of sociotechnical transition pathways. Research Policy 36(3):399-41. http://dx.doi. org/10.1016/j.respol.2007.01.003

Geertz, C. 1957. Ritual and social change: a Javanese example. American Anthropologist 59:32-54. http://dx.doi.org/10.1525/ aa.1957.59.1.02a00040

Gelcich, S., T. P. Hughes, P. Olsson, C. Folke, O. Defeo, M. Fernández, S. Foale, L. H. Gunderson, C. Rodriguez-Sickert, M. Scheffer, R. S. Steneck, and J. C. Castilla. 2010. Navigating transformations in governance of Chilean marine coastal resources. Proceedings of the National Academy of Sciences 107 (39):16794-16799. http://dx.doi.org/10.1073/pnas.1012021107

Giddens, A. 1976. New rules of sociological method: a positive critique of interpretative sociologies. Hutchinson, London, UK.
Giddens, A. 1979. Central problems in social theory: action, structure and contradiction in social analysis. University of California Press, Berkeley, California, USA.

Giddens, A. 1984. The constitution of society: outline of the theory of structuration. University of California Press, Berkeley, California, USA.

Government of Ontario. 2001. Oak Ridges Moraine conservation act. Ontario Ministry of Municipal Affairs, Toronto, Ontario, Canada. [online] URL: http://www.e-laws.gov.on.ca/html/ statutes/english/elaws statutes 01031 e.htm

Government of Ontario. 2002. Oak Ridges Moraine conservation plan. Ontario Ministry of Municipal Affairs, Toronto, Ontario, Canada. [online] URL: http://www.mah.gov.on.ca/Page1707. $\underline{\text { aspx }}$

Gunderson, L. H., and C. S. Holling, editors. 2002. Panarchy: understanding transformations in human and natural systems. Island, Washington, D.C., USA.

Gunderson, L. H., C. S. Holling, and S. S. Light. 1995. Barriers and bridges to the renewal of ecosystems and institutions. Columbia University Press, New York, New York, USA.

Kanter, R. 1990. Space for all: options for a Greater Toronto Area greenlands strategy. Ontario Ministry of Natural Resources, Toronto, Ontario, Canada. [online] URL: https://archive.org/ details/spaceforalloptio00kant

Kay, J. J., H. A. Regier, M. Boyle, and G. Francis. 1999. An ecosystem approach for sustainability: addressing the challenge of complexity. Futures 31:721-742. http://dx.doi.org/10.1016/ S0016-3287(99)00029-4

Kingdon, J. W. 1995. Agendas, alternatives and public policies. Second edition. Harper Collins, New York, New York, USA.

Levi-Strauss, C. 1962. La pensée sauvage. Librairie Plon, Paris, France.

Lewis, J. 2003. Design issues. Pages 47-76 in J. Ritchie and J. Lewis, editors. Qualitative research practice: a guide for social science students and researchers. Sage, Thousand Oaks, California, USA.

Loorbach, D., and J. Rotmans. 2006. Managing transitions for sustainable development. Pages 187-206 in X. Olshoorn and A. Wieczorek, editors. Understanding industrial transformation: views from different disciplines. Springer, Berlin, Germany.

Lucyk, C., R. Gibson, and P. H. Byer. 1989. The adequacy of the existing environmental planning approvals process for the Ganaraska watershed. Report 38 to the Minister of the Environment. Environmental Assessment Advisory Committee, Toronto, Ontario, Canada.

McCarthy, D. D. P. 2006. A critical systems approach to socioecological systems: implications for social learning and governance. Dissertation. University of Waterloo, Waterloo, Ontario, Canada. [online] URL: https://uwspace.uwaterloo.ca/bitstream/ handle/10012/2626/DM $\% 20$ Dissertation $\% 20-\% 20$ FINAL $\% 20$ for $\%$ 20Submission $\% 20-\% 20121806 . p d f ;$ jsessionid=D0D1EEBB63D68DB1E90C3B9CA75E3229? sequence $=1$ 
McCarthy, D. D. P., D. D. Crandall, G. S. Whitelaw, Z. General, and L. J. S. Tsuji. 2011. A critical systems approach to social learning: building adaptive capacity in social, ecological, epistemological (SEE) systems. Ecology and Society 16(3): 18. http://dx.doi.org/10.5751/ES-04255-160318

MacCracken, G. 1988. The long interview. Sage, Thousand Oaks, California, USA.

Maxwell, J. A. 1996. Qualitative research design. Applied social research methods series, volume 41. Sage, Thousand Oaks, California, USA.

Moore, M.-L., and F. R. Westley. 2011. Surmountable chasms: networks and social innovation for resilient systems. Ecology and Society 16(1): 5. [online] URL: http://www.ecologyandsociety. org/vol16/iss1/art5/

G. Mulgan, B. Sanders, R. Ali, and S. Tucker. 2007. Social innovation: what it is, why it matters and how it can be accelerated. Young Foundation, London, UK.

Neuman, W. L. 2000. Social research methods: qualitative and quantitative approaches. Allyn and Bacon, Toronto, Ontario, Canada.

Oak Ridges Moraine Technical Working Committee. 1994. The Oak Ridges Moraine strategy for the Greater Toronto Area: an ecosystem approach for long term protection and management. Government of Ontario, Toronto, Ontario, Canada.

Olsson, P., L. H. Gunderson, S. R. Carpenter, P. Ryan, L. Lebel, C. Folke, and C. S. Holling. 2006. Shooting the rapids: navigating transitions to adaptive governance of social-ecological systems. Ecology And Society 11(1): 18. [online] URL: http://www. ecologyandsociety.org/vol11/iss1/art18/

Parsons, T. 1951. The social system. Free Press, Glencoe, Illinois, USA.

Quist, J., and P. J. Vergragt. 2004. Backcasting for industrial transformations and system innovations towards sustainability: relevance for governance. Pages 409-437 in K. Jacob, M. Binder, and A. Wieczorek, editors. Governance for industrial transformation: proceedings of the 2003 Berlin conference on the human dimensions of global environmental change. Environmental Policy Research Centre, Berlin, Germany. [online] URL: http:// userpage.fu-berlin.de/ ffu/akumwelt/bc2003/proceedings/409\%20\%20437\%20quist.pdf

Riddell, D., F. Westley, and O. Tjornbo. 2012. Agency and innovation in a phase of turbulent change: conservation in the great bear rainforest. Pages 155-180 in K. Golden-Biddle and J. E. Dutton, editors. Using a positive lens to explore social change and organizations: building a theoretical and research foundation. Routledge, New York, New York, USA.

Ritchie, J., J. Lewis, and G. Elam. 2003. Designing and selecting samples. Pages 77-108 in J. Ritchie and J. Lewis, editors. Qualitative research practice: a guide for social science students and researchers. Sage, Thousand Oaks, California, USA.

Royal Commission on the Future of the Toronto Waterfront. 1992. Regeneration. Royal Commission on the Future of the Toronto Waterfront, Toronto, Ontario, Canada.
Selznick, P. 1957. Leadership in administration: a sociological interpretation. Harper and Row, New York, New York, USA.

Senge, P. M. 2010. The fifth discipline: the art and practice of the learning organization. Doubleday, New York, New York, USA.

Smith, A. 2007. Translating sustainabilities between green niches and socio-technical regimes. Technology Analysis and Strategic Management 19(4):427-450. http://dx.doi.org/10.1080/09537320701403334

Smith, A., and R. Raven. 2012. What is protective space? Reconsidering niches in transitions to sustainability. Research Policy 41(6):1025-1036. http://dx.doi.org/10.1016/j.respol.2011.12.012

Strauss, A. L. 1987. Qualitative analysis for social scientists. Cambridge University Press, Cambridge, UK. http://dx.doi. org/10.1017/CBO9780511557842

Taylor, S. J., J. Steven, and R. Bogdan. 1984. Introduction to qualitative research methods. John Wiley and Sons, New York, New York, USA.

Tushman, M., and E. Romanelli. 1985. Organizational evolution: a metamorphosis model of convergence and reorientation. Research in Organizational Behavior 7:171-222.

Walker, B. H., and D. Salt. 2006. Resilience thinking: sustaining ecosystems and people in a changing world. Island, Washington, D.C., USA.

Waltner-Toews, D., J. J. Kay, T. P. Murray, and R. C. Neudoerffer. 2004. Adaptive methodology for ecosystem sustainability and health (AMESH): an introduction. Pages 317-349 in G. Midgley and A. E. Ochoa-Arias, editors. Community operational research: systems thinking for community development. Plenum Publications/Kluwer Press, New York, New York, USA. http:// dx.doi.org/10.1007/978-1-4419-8911-6 14

Weber, M. 1978. Economy and society, volume 1. University of California Press, Berkely, California, USA.

Weber, M. 2009. The theory of social and economic organization. Free Press, New York, New York, USA.

Westley, F. R. 1992. Vision worlds: strategic vision as social interaction. Advances in Strategic Management 8:271-305.

Westley, F. R., and N. Antadze. 2010. Making a difference: strategies for scaling social innovation for greater impact. Innovation Journal: The Public Sector Innovation Journal 15(2). [online] URL: http://sig.uwaterloo.ca/sites/default/files/documents/ MAKING_A_DIFFERENCE_SiG_Format.pdf

Westley, F. R., and H. Mintzberg. 1989. Strategic vision and strategic management. Strategic Management Journal 10:17-32. http://dx.doi.org/10.1002/smj.4250100704

Westley, F., P. Olsson, C. Folke, T. Homer-Dixon, H. Vredenburg, D. Loorbach, J. Thompson, M. Nilsson, E. Lambin, J. Sendzimir, B. Banerjee, V. Galaz, and S. van der Leeuw. 2011. Tipping toward sustainabilityf: emerging pathways of transformation. $A M B I O$ 40:762-780. http://dx.doi.org/10.1007/s13280-011-0186-9

Westley, F. R., O. Tjornbo, L. Schultz, P. Olsson, C. Folke, B. Crona, and O. Bodin. 2013. A theory of transformative agency in linked social-ecological systems. Ecology and Society 18(3): 27. http://dx.doi.org/10.5751/ES-05072-180327 
Westley, F. R., B. Zimmerman, and M. Patton. 2006. Getting to maybe: how the world is changed. Random House, Toronto, Ontario, Canada.

Wheatley, M. J. 2006. Leadership and the new science: discovering order in a chaotic world. Berrett-Koehler, San Francisco, California, USA.

Whitelaw, G. S. 2005. The role of environmental movement organizations in land use planning: case studies of the Niagara Escarpment and Oak Ridges Moraine processes. Dissertation. University of Waterloo, Waterloo, Ontario, Canada.

Whitelaw, G. S., and P. F. J. Eagles. 2007. Planning for long, wide conservation corridors on private lands in the Oak Ridges Moraine, Ontario, Canada. Conservation Biology 21(3):675-683. http://dx.doi.org/10.1111/j.1523-1739.2007.00708.x

Whittington, R. 2007. Putting Giddens into action: social systems and managerial agency. Journal of Management Studies 29 (6):693-712. http://dx.doi.org/10.1111/j.1467-6486.1992.tb00685. $\underline{x}$

Whyte, W. F., editor. 1991. Participatory action research. Sage, Thousand Oaks, California, USA.

Woodhill, J. 2010. Capacities for institutional innovation: a complexity perspective. IDS Bulletin 41(3):47-59. http://dx.doi. org/10.1111/j.1759-5436.2010.00136.X

Yin, R. K. 2003. Case study research: design and methods. Third edition. Sage, Thousand Oaks, California, USA. 